\title{
Assessing the willingness of non-members to invest in new financial products in agricultural producer cooperatives: A choice experiment
}

\author{
Eeva Alho \\ Pellervo Economic Research PTT and University of Helsinki, Finland \\ e-mail: eeva.alho@ptt.fi
}

\begin{abstract}
The sourcing of outside investment capital from non-members has motivated the emergence of innovative cooperative structures, but the literature on these new organizational forms omits the perspective of an outside investor. This paper reports a study that applied a choice experiment method in a novel setting to increase understanding of the preferences of investors in agricultural firms. A large questionnaire dataset consisting of 845 financially literate subjects enabled testing of the form in which residual and control rights provide incentives for non-producer investors to invest in agricultural firms. The choice experiment data were analyzed using a latent class model. The results demonstrate that the subjects were interested in the currently hypothetical, new types of investment instruments in agricultural producer cooperatives. Three investor classes were distinguished based on the preferences: returnseeking, ownership-oriented and risk-averse investors. Who controls the firm appears to be irrelevant concerning willingness to invest, while the rural ties of the respondent are positively related to the preference for voting rights.
\end{abstract}

Key words: agricultural cooperative, agribusiness, investment decisions, Q13, Q14, G11

\section{Introduction}

Producer cooperatives play an important role in present-day agribusiness in the food supply chain of all EU member states (Bijman et al. 2012). However, the traditional model of agricultural cooperatives is being challenged. The opportunities of cooperatives to acquire growth capital are restricted to member contributions, which poses a financial handicap in competition against investor-owned firms (Chaddad et al. 2005). The organizational innovations seen in many agricultural cooperatives reflect the overall structural change that is ongoing in agriculture (Chaddad and Cook 2004, Valentinov 2007).

Innovative cooperative structures have emerged as a response to the competitive pressures (Chaddad and Cook 2004). Gaining access to growth capital from investors has for many been the reason to depart from the traditional cooperative organizational structure (Chaddad and Iliopoulos 2013). The objective of producer organizations is typically to find a model that retains the cooperative form and ideology but enables access to non-member equity capital (van Bekkum and Bijman 2006). The presence of a prominent shareholder, i.e. the agricultural producers, may give rise to agency problems between controlling shareholders and outside shareholders (Fama 1980, La Porta et al. 1999), while reduced liquidity as a consequence of block ownership may also make producer-owned firms unattractive for outside investors (Bolton \& von Thadden 1998). Moreover, if the cooperative attempts to compete with other firms for the raw material by offering a higher price to farmers, the lower rate of return on equity may make them unattractive as investments for outside investors. On the other hand, social capital inherent in agricultural cooperatives may motivate some producer-minded investors through the trust mechanism (Svendsen and Svendsen 2000). This study employed a choice experiment to elicit the preferences of non-farmer investors for various investment instruments that could be designed and brought into operation in order to attract growth capital for agricultural cooperatives.

In their sourcing of investment capital, agricultural organizations could benefit from findings in the existing literature that the investment decisions are to some extent driven by values and social influences. Presently, the literature in agricultural economics lacks evidence on the participation of non-producer investors in agribusiness firms. In this paper, we examine the link between the willingness of individuals to invest in different kinds of investment instruments of an agribusiness firm and their personal rural ties. A choice experiment method was employed to understand what types of attributes the non-producer investors would expect of the financial instruments in agribusiness and to identify preference heterogeneity among investors regarding agricultural production organizations. The objective was twofold: to examine investor preferences for the attributes of the financial instruments in agribusiness firms, and secondly, to identify different investor segments in order to facilitate the capital acquisition of the firms. The theoretical background of the paper is in behavioral finance and the literature on social influences in economic decisions. 
There is extensive empirical evidence for the role of behavioral factors in investment decisions and the preference of investors for familiar assets (French and Poterba 1991, Kang and Stulz 1997, Coval and Moskowitz 1999, Portes and Rey 2005). The effects of social capital and interpersonal interaction on economic outcomes are widely recognized in the economics literature (Knack and Keefer 1997, Guiso et al. 2004). Evidence on social influences has been established among individual investors in their personal savings and stock market participation decisions (Duflo and Saez 2002, Hong et al. 2004), but also in the contexts of professional decision making in financial markets (Lehmann and Neuberger 2001, Pool et al. 2014). Geographical bias may result from investors' preferences for familiar investments (Huberman 2001). Morse and Shive (2011) found that group identity, i.e. the sense of belonging to a specific group of people, affects portfolio choices.

Individuals derive economic utility if they act in adherence to an identity that matches particular values (Akerlof and Kranton 2000). The phenomenon is manifested in consumption decisions, when identity affects brand choices and switching (Lam et al. 2010) and breeds customer loyalty (Homburg et al. 2009). Evidence from agricultural economics corroborates the notion that subjective values are powerful drivers of economic and consumption decisions: Attitudes explain consumer aversion to hormone-treated beef (Lusk et al. 2003) and the preference for genetically modified (GM) vs. non-GM food (Baker and Burnham 2001).

Some of the mechanisms underlying how personal experiences and social identity affect economic outcomes relate to the environment in which a person grows up, which affects preferences and beliefs later in life (Guiso et al. 2004, Malmendier and Nagel 2011). Social identity theory states that belonging to the same group fosters bonding between people, with binding ties forming between members of a family, school, work place, or community (Tajfel and Turner 1979, Akerlof and Kranton 2000). Prior evidence indicates that farm-born individuals develop strong emotional ties to rural values that remain throughout their lives (Cassidy and McGrath 2014). Building on the previously discussed evidence on the effects of personal experience and social identity on economic decisions, we hypothesize that a similar mechanism may be at work in investment decisions regarding agricultural firms involved in food production. More specifically, this study investigated the effects of the living environment and identity on investment preferences. These variables were defined as person currently living in an urban or rural area and the self-reported rural identity. These social influences on investment preferences were tested in a large sample of professional financial advisers using a survey that included a choice experiment regarding the attributes of financial instruments.

The attributes represent currently available stock investments as well as hypothetical, yet possible, new features under the Finnish cooperative law, which would enable agricultural producer cooperatives to source investment equity capital from non-farmer and non-member investors. The objective of this study was twofold. First, this study sought to identify the preferred attributes that would assist the cooperative management to design such new instruments. The latent class model enabled the discerning of investor profiles and distinct investment preferences for investment instruments in agribusiness firms. Second, the relationship between investment preferences and personal factors, i.e. a self-reported rural identity and a rural domicile, was investigated in the three observed investor classes with a logit regression.

The pool of experimental subjects represented potential retail investors and was composed of Finnish financial market professionals who held the diploma for certified financial advisers (i.e. the Finnish national equivalent of the international CFA diploma). The sample formed a group of informed and financially literate individuals. Many of them were likely to have personal experience of investing either their own wealth or in their work position. Using this pool of respondents mitigated the common problems observed in the literature on economic decisions if they draw conclusions on market behavior from laboratory studies or experiments involving student subjects (Harrison and List 2004). However, the prevailing practice in the choice experiment literature is to use a representative sample of the population in order to elicit preferences in the field. The respondents were, however, advised to express their preferences as private investors and considering their own portfolio choices instead of in their possible role as delegated portfolio managers. The choices were analyzed with a latent class model, which enabled the analysis of preference heterogeneity.

The contribution of this study to the existing literature is twofold. First, this is the only study that has examined cooperative finance from the perspective of non-member investors. Second, the choice experiment method has been scarcely utilized in studies on financial preferences and on the design of investment instruments in agribusiness. Similarly to this study, Anastassiadis and Musshoff (2013) presented hypothetical investment alternatives to farmers and examined how investment profitability, risk, and financial flexibility affect the farmers' decisions. Their approach with the choice experiment was to uncover preferences for the use of debt capital in adaptation 
investments in agricultural production, while we were interested in the availability of investment capital among non-farmer investors. To our knowledge, this paper reports the first study employing the choice experiment method to examine non-farmer investment preferences in the agribusiness sector. The rest of the paper proceeds as follows: The data and methods are described in section 2. Section 3 presents the results, which are discussed in section 4.

\section{Data and methods}

We used the discrete choice experiment method, in which the subjects are presented with a number of choice sets that represent several alternatives characterized by a set of attributes. The method is presented, for example, in Hensher et al. (2015). The subjects are requested to choose the most preferred alternative in each choice task, which is assumed to give the greatest utility to the individual. The theoretical framework is the random utility theory and neoclassical consumer theory (Thurstone 1927, Lancaster 1966, McFadden 1986), according to which the trade-offs made by the respondent in the choice tasks and the relative preferences for attributes of the alternatives can be estimated. As a stated preference method, the choice experiment method is often used to test the preferences of individuals in a hypothetical situation, for example regarding new products or policies, when revealed preference data are not available.

Choice experiments have been extensively employed in the fields of transport (Hensher and Rose 2007), recreation (Train 1998, Boxall and Adamowicz 2002), marketing (Batsell and Louviere 1991, Louviere et al. 2010, Probst et al. 2012), health (McIntosh and Ryan 2002, Hole et al. 2013, Lagarde 2013), and various environmental valuation contexts (Scarpa et al. 2009). In agricultural economics, choice experiments have increasingly been used in the assessment of farm management policies and environmental schemes (Jaeck and Lifran 2014, Kragt and LlewelIyn 2014, Schulz et al. 2014), as well as in the estimation of consumer demand for various food quality attributes (e.g. Lusk et al. 2003, Scarpa et al. 2005, Caputo et al. 2013, Emberger-Klein et al. 2015). Recently, a number of studies have also used choice experiments to explore behavioral issues related to consumer choices (Swait and Adamowicz 2001, Balcombe et al. 2014, Caputo et al. 2016, De Marchi et al. 2016).

In the field of investments, the choice experiment method is underutilized. Analyses on investor behavior have traditionally relied on time series of market prices, transactions, or holdings, but more recently also on field experiments. The use of surveys in the study of financial decision making has gained ground (Nagy and Obenberger 1994, Kruse and Thompson 2003, Glaser et al. 2007), as their value in generating new datasets is being recognized and the potential hypothetical bias is being addressed. Choice experiments require the decomposition of the options into attributes and their levels, which may be an almost insurmountable task of simplifying real-life investment situations. A few choice experiment studies have, however, successfully applied the method to investment decisions and utilized latent class models to identify investor heterogeneity (Bateman et al. 2011, Anastassiadis and Musshoff 2013).

\section{Data}

The data consisted of responses to a questionnaire targeted at Finnish financial market professionals, who represented a group of informed subjects. The sample was based on the register of persons who had completed the diploma for certified financial advisers during the period from January 2009 to June 2014. The diplomas are administered by the Finnish Association of Securities Dealers and Aalto Executive Education, which provided confidential access to the register. The certification diplomas have two levels: the General Securities qualification (APV1) and the Investment Adviser qualification (APV2). In Finland, individuals in the investment adviser profession are not required to hold the diploma, but in practice many professionals in banks and customer service positions in the finance sector take the examination at some stage in their career. The subjects were briefed to respond to the questionnaire as private persons and not in their possible role as bank representatives, since the questions were not intended to analyze the investment or customer policies of their employers.

In total, approximately 13000 persons have completed the diploma since the introduction of the examinations, which equals roughly a third of employees in the financial sector in Finland (Federation of Finnish Financial Services 2015). The financial industry has undergone such major structural changes in recent years that the contact information may be outdated if the sample were extended to before 2009. A request to complete the Internet-based questionnaire was sent to 7200 persons via email in October 2014. Approximately 1200 email addresses returned a non-reception message, and these persons were thus lost from the initial sample. After one reminder, 845 individuals responded to the questionnaire, yielding a response rate of $14 \%$. The final data included the first-phase responses, which were collected from a pilot sample of a hundred randomly chosen financial advisers. 
The sample was slightly unbalanced in terms of gender, as 540 (64\%) respondents were females and 305 (36\%) were males. However, this reflects the gender distribution in the financial sector in Finland, as $70 \%$ of employees in banking were females in 2011 (Federation of Finnish Financial Services 2013). The average age of all respondents was 41 years, and the average age for females and males, respectively, was 43 and 38 years. The median age in the financial sector in Finland was 45 years (Federation of Finnish Financial Services 2013).

The questionnaire gathered background information on the characteristics of the respondents. These variables described the work experience of the investment professionals included in the sample. The majority of the respondents were employed in a bank or brokerage. The typical position was an investment adviser, while approximately one-fifth of respondents were currently in a management position. In line with the overall demographics of the sector, bank management positions are male dominated, and typical job titles of female employees are in customer service and service advisory positions. The final sample consisted of rather experienced financial professionals, as about half had over 15 years of work experience in the sector and $30 \%$ had over 25 years of experience. Table 1 reports the variables and the sample averages.

\begin{tabular}{|c|c|c|}
\hline Variable & Explanation and measurement & Average (SD) \\
\hline Identity & $\begin{array}{l}\text { Qualitative measure, indicating the person's agreement with the } \\
\text { statement 'Rural life forms an important part of my identity', range } \\
1-5 \text { where } 1=\text { strongly disagree... } 5=\text { strongly agree }\end{array}$ & $\begin{array}{c}3.35 \\
(1.40)\end{array}$ \\
\hline Risk aversion & $\begin{array}{l}\text { Qualitative measure, indicating the person's agreement with the } \\
\text { riskiness of stock investments, range } 1-5 \text { where } 1 \text { = strongly disagree... } \\
5=\text { strongly agree }\end{array}$ & $\begin{array}{c}2.48 \\
(1.16)\end{array}$ \\
\hline Living rural & $\begin{array}{l}\text { Dummy variable indicating the place of domicile, whether the person } \\
\text { is currently domiciled in a rural community }\end{array}$ & $\begin{array}{c}0.26 \\
(0.44)\end{array}$ \\
\hline $\begin{array}{l}\text { Production } \\
\text { structure }\end{array}$ & $\begin{array}{l}\text { Workplace structure in the person's current place of domicile, } \% \text { of } \\
\text { inhabitants in the postal code area employed in the agriculture sector }\end{array}$ & $\begin{array}{c}5.11 \% \\
(10.86)\end{array}$ \\
\hline $\begin{array}{l}\text { Work in } \\
\text { agrifinance }\end{array}$ & $\begin{array}{l}\text { Frequency variable indicating whether the work duties involve } \\
\text { agricultural finance, range } 1-5 \text { where } 5=\text { once a week or more } \\
\text { often, } 4=\text { at least once a month, } 3=\text { a couple of times a year, } 2=\text { less } \\
\text { frequently, } 1=\text { never }\end{array}$ & $\begin{array}{c}1.96 \\
(1.13)\end{array}$ \\
\hline Training & $\begin{array}{l}\text { Dummy variable indicating whether the person has participated in } \\
\text { training in agricultural finance }\end{array}$ & $\begin{array}{c}0.17 \\
(0.38)\end{array}$ \\
\hline Sex & Dummy variable, $0=$ male, $1=$ female & $\begin{array}{c}0.64 \\
(0.48)\end{array}$ \\
\hline Age & Years & $\begin{array}{c}42 \\
(10.99)\end{array}$ \\
\hline Experience & Work experience in the sector, years & $\begin{array}{c}16 \\
(12.14)\end{array}$ \\
\hline Education & $\begin{array}{l}\text { The highest completed degree, range } 1-5 \text { where } 1=\text { primary school, } \\
2=\text { vocational, } 3=\text { secondary school, } 4=\text { polytechnic, } 5=\text { university }\end{array}$ & $\begin{array}{c}4.0 \\
(0.83)\end{array}$ \\
\hline Manager & $\begin{array}{l}\text { Dummy variable indicating whether the person is in a managerial } \\
\text { position }\end{array}$ & $\begin{array}{c}0.25 \\
(0.43)\end{array}$ \\
\hline $\begin{array}{l}\text { Number of } \\
\text { respondents }\end{array}$ & & 845 \\
\hline
\end{tabular}

\section{Survey design}

This survey was conducted as part of a larger research project whose overall purpose is to develop new ways to diversify the financing opportunities of agricultural producer cooperatives. As the first part of the project, a large farmer survey employed a choice experiment to determine the preferred attributes of the new financial instruments that would enhance the possibilities of farmers to participate in financing the cooperative investments. The attributes used in the farmer survey were theoretically based on the Chaddad and Cook (2004) ownershipcontrol rights typology of agricultural cooperatives, but they were adapted to the Finnish context. This survey was instead designed to similarly test the preferred attributes of the new financial instrument, but now from the perspective of non-members, i.e. outside investors. The objective of this choice experiment for investors was to test as closely as possible the same attributes that were tested with the farmers. The farmer and the investor surveys 
thus ideally served as mirror images of each other. The selection of the attributes in the farmer choice experiment was based on a focus group interview in addition to the Chaddad and Cook (2004) typology, and the farmer survey had already been conducted and analyzed prior to the design of this investor choice experiment. Thus, the selection of the attributes in the investor choice experiment was thoroughly grounded, and, in addition, the design of the choice experiment, as well as the whole survey, was pre-tested with a small sample before sending it out to the financial adviser sample.

The four choice attributes of financial investments in agricultural producer cooperatives were the voting right, return right, capital appreciation, and expected return and risk (Table 2). The attributes that were selected capture the main components inherent in any type of financial investment were the risk and return levels, the right to exercise control through voting, and the mechanism for capital returns. The objective of these attributes was to test the appeal of non-traditional stock investment instruments, while at the same time, these attributes could be used to construct investment instruments bearing some resemblance to the cooperative capital investments that cooperative members subscribe to. The attributes were kept simple to reduce the cognitive burden on the respondents, but also to keep the focus on the key elements that Finnish cooperative law enables to be modified from the basic cooperative capital to allow non-members to invest in the cooperative. Each attribute had three qualitative levels. In the case of the return right, capital appreciation, and expected risk and return attributes, the first level corresponded to the terms of an ordinary stock investment and the two alternative levels represented shifts towards cooperatives. In case of the voting right attribute, the levels were chosen to describe the control structure of the firm so that the attribute levels defined how the votes were balanced between farmers and investors.

Table 2. Attribute description and levels used in the investment choice experiment

\begin{tabular}{|c|c|c|}
\hline Attribute & Description & Levels \\
\hline Voting right & $\begin{array}{l}\text { The entitlement to vote. In the first option, the } \\
\text { votes are exclusively restricted to the producers. } \\
\text { In the other options, non-producer investors are } \\
\text { endowed with voting rights, but the control block } \\
\text { held by the producers varies. }\end{array}$ & $\begin{array}{l}\text { 1. No voting right } \\
\text { 2. Voting right, ownership is dispersed } \\
\text { 3. Voting right, producers have majority ownership }\end{array}$ \\
\hline Return right & The form of the payment of the investment return & $\begin{array}{l}\text { 1. Dividend } \\
\text { 2. Preferred dividend } \\
\text { 3. Fixed interest return }\end{array}$ \\
\hline $\begin{array}{l}\text { Capital } \\
\text { appreciation }\end{array}$ & $\begin{array}{l}\text { The treatment of the invested capital. The value } \\
\text { may fluctuate daily in a marketplace or the nominal } \\
\text { may be safe and returned at nominal value or } \\
\text { appreciate through bonus issues following the } \\
\text { firm results. }\end{array}$ & $\begin{array}{l}\text { 1. Valued in a secondary market } \\
\text { 2. Capital remains and is returned at nominal value } \\
\text { 3. Capital remains and nominal is adjusted for the } \\
\text { appreciation of firm value }\end{array}$ \\
\hline $\begin{array}{l}\text { Expected } \\
\text { return } \\
\text { and risk }\end{array}$ & Annual rate of return & $\begin{array}{l}\text { 1. } 8 \% \text {, high risk } \\
\text { 2. } 5 \% \text { moderate risk } \\
\text { 3. } 2 \% \text { low risk }\end{array}$ \\
\hline
\end{tabular}

Prior to the choice sets, an introductory statement explained that the objective of the questions was to examine how the investment attributes affect the investment decision. The respondents were briefed that the choice situations represent equity claims in food chain companies in which the agricultural producers are also owners. The term 'agricultural producer cooperative' was not directly mentioned in the briefing for two reasons. First, the choice experiment included attribute levels that defined cooperatives unconventionally compared to what is typically associated with the traditional cooperative form. Secondly, the attribute levels were defined as generally as possibly in order to avoid tying them explicitly to any organizational form. If any respondent had prejudice against cooperatives, the absence of this term from the briefing should not discourage anyone from stating their preferences regarding the investment attributes in a firm, which may now be a cooperative but may perhaps transform into an investor-oriented firm later.

The attribute levels were then presented in the briefing, after which the respondents were instructed to weigh the choice tasks with regards to their own surplus savings that could be allocated to investing and were not set aside for consumption. The standard cheap talk script was included in the instructions to mitigate the hypothetical bias that always constitutes a risk in stated preference studies (Landry and List 2007, Hensher 2010). The benefits of including a cheap talk script in choice experiment instructions are evidenced in Ladenburg et al. (2010). The level of wealth and size of the surplus savings of a respondent may have an impact on his or her choices, but these potential effects were not controlled for in the modeling. The reason is twofold. First, as the purpose of the choice experiment was to determine the relative preference for the investment attributes as such, the level of the 
available investment capital of the respondents was not the main focus here. Second, self-reported amounts of investment capital could be subject to hypothetical bias, and they could suffer from differences in how individuals define their surplus wealth amounts that could be available for placing in new investment instruments. Having to think about the portfolio allocations and the exact amounts of investable assets would have made the choice task very burdensome for the respondents, which might have reduced the response rate.

To form the choice experiment tasks, a fractional factorial design was generated with Ngene software (ChoiceMetrics Ltd, Sydney). We used a D-efficient design with no prior information. The final design achieved a D-error of 0.024 . This was the design that produced the lowest D-error: it was expected to produce smaller parameter variances and covariances, and was therefore considered D-efficient (Scarpa and Rose 2008). A total of 36 choice sets was generated and split into six blocks to limit the number of tasks per respondent. Thus, each respondent was presented with six choice sets that each offered three alternatives. A two-staged task was used: first, a forced choice included only two investment alternatives describing the new instrument and asked the respondent to choose between these, after which an unforced choice also incorporated the third alternative, the opt-out or no-choice alternative. Previous studies using a two-stage choice task include those by Hensher (2004), Hess and Rose (2009), and Hensher (2010). The opt-out was defined as keeping the investment wealth in a bank account earning $1 \%$ return instead of allocating wealth to either of the new instruments. This represents a riskless alternative. The interest level approximated the level offered by Finnish banks for time deposits or savings accounts of retail customers at the time when the questionnaire was conducted (the rates are available via the Bank of Finland statistics website).

The idea of providing the opt-out choice in the form of a bank account instead of constructing the reference alternative from the attribute levels describing the ordinary stock investment is that an investor in reality also has the opportunity to hold the savings in his or her bank account instead of allocating them to (risky) investments. This 'no-choice' alternative represents a standard alternative way of designing the choice situations (Louviere et al. 2000, Hensher et al. 2015), and in this design, the no-choice alternative is devoid of attribute levels. The opt-out or no-choice alternative remains, however, an alternative with an associated utility that can be estimated (Hensher et al. 2015). If the reference alternative were given in the form of traditional stock investment, the choice task would have had to meticulously define the sector and other characteristics for the alternative, because there is no generic 'stock' in the market. Indeed, the objective of the choice experiment design was not to test the portfolio allocations of the investors over different sectors, but rather to investigate the relative preferences regarding the attribute levels, which vary the terms and conditions regarding how much control and residual rights investors would require in order to place their investment capital in the new cooperative instruments. In addition, the design reflects the fact that the majority of (other than the residential) assets of Finnish households are held in savings accounts (Statistics Finland 2013), and the definition of the status quo as a bank account rather than as a stock holding is more likely to represent the current situation of a respondent.

The two-staged task aimed at getting the respondents to concentrate on the attributes, but to mitigate the problems associated with forced choice tasks (Rose and Hess 2010). If the opt-out were given outright, it might have provided an easy escape for the respondents from a difficult choice task and distorted the preference estimation (Kontoleon and Yabe 2003). It is worth noting the possibility that in the two-stage choice task, the respondents might have adhered to the initial choice that they made in the forced choice task when the opt-out option was not present. The inclusion of an opt-out or no choice alternative is essential in addressing the potential hypothetical bias, although in the absence of a payment attribute, the potential bias would not cause harm as inflated willingness-to-pay estimates in this study. Dhar and Simonson (2003) argue that if the inclusion of the opt-out draws more responses from some options relative to others, it indicates a violation of the independence of irrelevant alternatives (IIA). Their findings imply, for instance, that an alternative that is average by its attribute levels loses relative share, because when consumers who are uncertain about their preferences are forced to make a choice, they tend to avoid regret by opting for a compromise alternative. The implications of the inclusion of the opt-out alternative are not analyzed further in our paper, but are left for future research. The unforced task with an optout provided the main data used for analysis.

The choice data are effects coded in order to allow coefficients to be estimated for all levels of the attributes (Louviere et al. 2000). The choice sets were organized in a random order to mitigate any effects on the estimates from the ordering of the attributes. The first section of the questionnaire presented a set of introductory questions about the investment criteria in general and the significance of agriculture and the countryside. The second section comprised the choice experiment tasks. Figure 1 presents an example of a choice task. The final section included statements about the ownership of a firm on a Likert scale, after which the respondents were requested to fill in their background information. The online questionnaire consisted of 16 pages, and on average, it took 16.5 minutes to complete the whole questionnaire. 


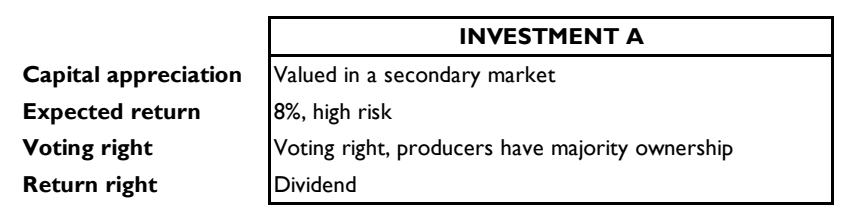

\begin{tabular}{|l|}
\hline \multicolumn{1}{|c|}{ INVESTMENT B } \\
\hline Capital remains \& adjusted for appreciation of firm value \\
$2 \%$, low risk \\
No voting right \\
Fixed interest return \\
\hline
\end{tabular}

BII. Please choose from the alternatives presented above the investment that you prefer the most. I choose $X$ Investment $A$

$X$ Investment $B$.

BI2. Now you have also the possibility to choose the bank account earning $1 \%$ return. Which alternative do you choose now? $X$ Investment $A$

$X$ Investment B

$X$ Neither. I save the money in a bank account and earn $1 \%$ interest.

Fig. 1. Example of a choice task

\section{Econometric modeling}

The choice experiment data were analyzed with a latent class logit model (LCM). This has been employed in many fields of applied economics, for instance in studies on recreation choices (Boxall and Adamowicz 2002), environmental economics (Birol et al. 2006, Morey et al. 2006), preferences for travel modes (Greene and Hensher 2003, Wen and Lai 2010), farmer preferences for production technologies (Jaeck and Lifran 2014), and consumer preferences for food products (Bechtold and Abdulai 2014, Yue et al. 2015). Latent class models are used to identify preference heterogeneity among consumers (Boxall and Adamowicz 2002). Accounting for heterogeneity gives a more realistic description of the preferences for goods and services and thus enables unbiased estimation models (Boxall and Adamowicz 2002). In an LCM, the consumers are grouped into classes, within which the preferences are relatively homogeneous but between which the preferences are assumed to vary. These latent classes correspond to underlying market segments characterized by different tastes (Louviere et al. 2000), which is why the method has appeal in marketing literature.

Multinomial logit ( $\mathrm{MNL}$ ) models are frequently used as a baseline to estimate the choice experiment data and the preferences for the attributes (e.g. Lusk et al. 2003, Kragt and Llewellyn 2014, Schultz et al. 2014). These models have an implicit assumption that all the respondents possess similar preferences. A latent class model is ideal for identifying investor segments in which individuals possess similar attribute preferences that are distinct from the other segments (Swait 1994, Boxall and Adamowicz 2002). Latent class models provide an alternative to MNL models and are an approach to capture preference heterogeneity. In comparison to mixed logit models, which also relax the assumption of independence from irrelevant alternatives (IIA), an LCM approximates the underlying distribution of preferences with a discrete approach, but no assumptions about the distribution have to be made (Greene and Hensher 2003). Parameter heterogeneity across individuals is modeled with a fixed set of classes (Greene 2007). As the membership of an individual in a class is latent, and cannot therefore be observed by the analyst, it is determined based on the preferences for the attributes. Each class is characterized by class-specific parameter estimates.

There is no absolute answer concerning which modeling approach is suitable for the data and research question at hand, and the choice rests with the researcher. In an LCM, a researcher does not need to take a stand on which of the variables produce heterogeneity in preferences (Greene and Hensher 2003). Shen (2009) compared LCMs with mixed logit models, finding that LCMs performed better in two transport mode choice datasets. Examples in the field of environmental economics include Boxall and Adamowicz (2002), Morey et al. (2006), and Birol et al. (2006), who estimated both random parameter logit and latent class models. Consistently with Shen (2009), their findings suggest that LCMs are superior, and that the heterogeneity is more interpretable than in random parameter models with interactions.

In this study, it was realistic to assume preference heterogeneity among investors, and another modeling approach to accompany the MNL was thus needed. We preferred the latent class model over mixed logit models, because the estimation result is not influenced by the selection of the underlying distribution (Greene and Hensher 2003), and the result gives easily interpretable discrete classes of investors. As the LCM estimation represents heterogeneity between the discrete classes but assumes homogeneous preferences within a class, the results may advise policy makers on the actions needed when targeting investment products at different investor segments. Thus, targeted marketing efforts can be planned regarding the investments in agribusiness if the investor groups are identified. 
Although the investment alternatives of the choice tasks were composed of rather general investment attributes comparable to any sector, the framing of the choice situation in agricultural production and the food industry may have appeared more preferable to some segments of respondents. Risk tolerance is also expected to affect the choices and the relative valuations of the attributes, causing another source of heterogeneity. The class membership of the respondents was explained with sociodemographic variables, identity, rural ties, and risk aversion using a binary probit model in order to profile the investors.

The analytical framework of discrete choice models is the economic theory of consumer behavior and random utility theory (Lancaster 1966, McFadden 1974). A consumer is assumed to choose the alternative $I$, described by a number of attributes $A_{k}(k=1,2, \ldots, K)$ and a number of attribute levels $A_{k l}(I=1,2, \ldots, L)$, that offers the greatest utility $U_{1}=V\left(A_{1,}, A_{21}, \ldots, A_{k l}\right)+e_{1}$, where $V\left(A_{1,}, A_{21}, \ldots, A_{k l}\right)$ is the systematic part of utility and $e_{1}$ is the random component (Carson et al. 1994).

The latent class model used in this study is defined as follows:

$$
U_{j i t \mid c}=\beta_{c}^{\prime} x_{j i t}+\varepsilon_{j i t}
$$

in which investor $i(i=1,2, \ldots, N)$ selects the alternative $j$ with the preferred set of ownership right attributes $\mathbf{x}_{j i t}$ from the given $\mathrm{M}$ alternatives $(j=1,2, \ldots \mathrm{M})$. The alternatives are described with four attributes and the alternatives give two policy options, i.e. new investment instruments in agricultural cooperatives and the opt-out. The utility $U_{j i t}$ maximizing choice is made in $t$ choice tasks $(t=1,2, \ldots \mathrm{T}) . \varepsilon_{j i t}$ describes the unobserved heterogeneity for individual $i$ and alternative $j$ in choice situation $t$ and $\beta_{c}$ is the class-specific parameter vector. Utility associated with the opt-out does not consist of any other attributes apart from the risk-free deposit account interest. The alternative specific constant (ASC) was defined to take the value of one for the investment alternatives.

The latent class model estimates the taste parameters $\beta_{c}$ within each class and the class probabilities $\theta_{c}$. Within the class, choice probabilities are assumed to be generated by the multinomial logit model, when

$$
P\left[y_{i t}=j \mid c\right]=\left(\exp \left(\beta_{c}^{\prime} x_{j i t}\right)\right) /\left(\sum_{j=1}{ }^{j i} \exp \left(\beta_{c}^{\prime} x_{j i t}\right)\right)
$$

Class probabilities are determined by

$$
P[c]=Q_{i c}=\left(\exp \left(\theta_{c}^{\prime} z_{i}\right)\right) /\left(\sum_{c=1} c \exp \left(\theta_{c}^{\prime} z_{i}\right)\right), \theta_{c}=0,
$$

where $z_{i}$ is a set of individual-specific characteristics. The probabilities may be determined without the characteristics, as a function of only parameters $\theta_{c}$.

For a given individual, the probability of a specific choice is estimated as the expected value of the class-specific probabilities, given by

$$
P\left(y_{i t}=j\right)=\sum_{c=1}^{c} P(c)\left[\left(\exp \left(\beta_{c}^{\prime} x_{j i t}\right)\right) /\left(\sum_{j=1}^{j i}\left(\beta_{c}^{\prime} x_{j i t}\right)\right)\right]
$$

BIC and AIC criteria are used to determine the optimal number of classes (Boxall and Adamowicz 2002). The lower the AIC or BIC, the better is the fit of the specification. The latent class and multinomial logit models were estimated using Nlogit 4.0 (Econometric Software Inc., Plainview).

\section{Results}

This section first reports the results of the latent class estimation, which distinguished investor groups based on their choices. Class membership was then explained in a binary logit model with individual background factors.

Latent classes and the membership of respondents in the classes are identified based on the choices they make. The BIC and AIC criteria indicated that the preferred model in this study has either three or four classes. (The values are available from the author upon request.) The model with three classes, in which the BIC value is minimized, yields clearly identifiable investor classes, so this model is reported here as the main result. 
Investor preferences for the investment instruments were distinguished by three latent classes, whose estimated coefficients are presented in Table 3. A positive (negative) sign for an attribute coefficient indicates an increasing (decreasing) probability of choosing the investment alternative. Rather than the absolute values of coefficients, the relative differences and preferences among the chosen attributes are of interest. A negative coefficient for the opt-out alternative indicates that a respondent derives utility from choosing a bank account deposit over the investment alternatives A or B. A positive ASC indicates that an individual prefers the new investment instruments over keeping the investment wealth in a bank account.

Table 3. Estimates of the multinomial and latent class models

\begin{tabular}{|c|c|c|c|c|}
\hline & $\begin{array}{l}\text { Baseline MNL } \\
\text { (SD) }\end{array}$ & & $\begin{array}{l}\text { ent class moc } \\
\text { (SD) }\end{array}$ & \\
\hline Variable & & $\begin{array}{l}\text { Class } 1 \\
\text { Return seeking }\end{array}$ & $\begin{array}{c}\text { Class } 2 \\
\text { Ownership }\end{array}$ & $\begin{array}{c}\text { Class } 3 \\
\text { Risk averse }\end{array}$ \\
\hline $\mathrm{ASC}^{1}$ & $\begin{array}{c}1.20 * * * \\
(0.07)\end{array}$ & $\begin{array}{c}2.38 * * * \\
(0.26)\end{array}$ & $\begin{array}{c}3.08 * * * \\
(0.13)\end{array}$ & $\begin{array}{c}-1.03^{* * *} \\
(0.14)\end{array}$ \\
\hline Voting right & $\begin{array}{l}0.13^{*} \\
(0.07)\end{array}$ & $\begin{array}{l}-0.31 \\
(0.31)\end{array}$ & $\begin{array}{c}0.65 * * * \\
(0.18)\end{array}$ & $\begin{array}{c}0.04 \\
(0.10)\end{array}$ \\
\hline Producer majority & $\begin{array}{c}0.01 \\
(0.05)\end{array}$ & $\begin{array}{c}0.20 \\
(0.16)\end{array}$ & $\begin{array}{l}-0.02 \\
(0.78)\end{array}$ & $\begin{array}{c}0.02 \\
(0.10)\end{array}$ \\
\hline Preferred dividend & $\begin{array}{c}-0.15^{* * *} \\
(0.04)\end{array}$ & $\begin{array}{c}-0.16^{* *} \\
(0.08)\end{array}$ & $\begin{array}{c}-0.35^{* * *} \\
(0.06)\end{array}$ & $\begin{array}{c}-0.21^{* *} \\
(0.10)\end{array}$ \\
\hline Fixed interest & $\begin{array}{c}0.12 * * * \\
(0.04)\end{array}$ & $\begin{array}{l}-0.08 \\
(0.07)\end{array}$ & $\begin{array}{c}0.56 * * * \\
(0.06)\end{array}$ & $\begin{array}{c}0.30 * * * \\
(0.10)\end{array}$ \\
\hline Returned at nominal & $\begin{array}{c}0.33 * * * \\
(0.04)\end{array}$ & $\begin{array}{c}0.27 * * * \\
(0.09)\end{array}$ & $\begin{array}{c}0.51 * * * \\
(0.07)\end{array}$ & $\begin{array}{c}0.85 * * * \\
(0.08)\end{array}$ \\
\hline Appreciates & $\begin{array}{l}-0.01 \\
(0.04)\end{array}$ & $\begin{array}{l}-0.09 \\
(0.07)\end{array}$ & $\begin{array}{c}0.17 * * * \\
(0.05)\end{array}$ & $\begin{array}{c}-0.23^{*} \\
(0.12)\end{array}$ \\
\hline Expected return & $\begin{array}{c}0.12 * * * \\
(0.01)\end{array}$ & $\begin{array}{c}0.36 * * * \\
(0.02)\end{array}$ & $\begin{array}{c}-0.11^{* * *} \\
(0.01)\end{array}$ & $\begin{array}{c}-0.05^{*} \\
(0.03)\end{array}$ \\
\hline Probability of class & & $0.55^{* * *}$ & $0.34 * * *$ & $0.12^{* * *}$ \\
\hline $\mathrm{N}$ of observations & 5070 & 5070 & & \\
\hline Log likelihood & -4568.13 & -3677.31 & & \\
\hline Pseudo R squared & 0.03 & 0.34 & & \\
\hline
\end{tabular}

The ASC is positive in both classes 1 and 2, meaning that these investor types were willing to invest in the given alternatives of the agricultural producer cooperatives. The first identified class comprised $55 \%$ of the respondents. The preferences of this class can be characterized as return seeking. The dimension that most clearly sets apart these respondents from other classes is the strong preference for a higher expected return and risk. A higher risk inherently goes hand in hand with the return, so we conclude that these respondents were more risk tolerant in their investments than the others. Investors in class 1 were not interested in voting rights, as both of the voting attribute levels were statistically nonsignificant. However, although the block ownership of the producers was no obstacle to investing, neither was it a valued attribute. A preference for returning the nominal value of the investment suggests the valuing of capital security, but this disposition was observed in all three classes, while the coefficient was relatively smaller in class 1.

In class 2, the investors exhibited a strong preference for the voting right attached to the investment instrument, which is in stark contrast to class 1 . The share of the respondents belonging to this class was $34 \%$. Class 2 investors were also indifferent to the block ownership of producers. In addition to a preference for a lower expected return and risk, and thus also for a lower risk level, investors in this class had a tendency to choose the alternatives that feature the safety of the capital and return. The investors preferred a fixed return over a variable dividend. Both treatments of the capital, which promised either the return of the capital or the adjustment of the nominal for the appreciation of firm value, were preferred over the market-to-market valuation of the instruments in a secondary market. 
In contrast to classes 1 and 2, investors belonging to class 3 refrained from choosing the new instruments, but instead preferred a deposit account yielding a $1 \%$ annual return. In line with the negative ASC, the other estimated coefficients indicate a preference for deposit-like investments that entitle the return of the nominal at the end of the investment period and a fixed interest return. We conclude that the choice of the opt-out may indicate risk aversion rather than a bias towards the sector or farmer ownership, since the investors in this class were indifferent to the attributes regarding the voting rights in the firm. Specifically, if the investors shied away from cooperative investments due to aversion to the farmer block in firm control and the perceived inferior position of minority investors, this should be revealed by a negative coefficient for the attribute level 'Producer majority', which is not the case.

Class 3 included $12 \%$ of the respondents. The class probability corresponds with the proportion of respondents who disagreed with the statement "Food production firms provide an attractive investment opportunity", which was included in one section of the questionnaire measuring investment attitudes. Measured on a Likert scale from 1 to 5 , in which 5 indicated strongly agree and 1 indicated strongly disagree, $11.6 \%$ of the respondents disagreed with the statement, while $63.8 \%$ of the respondents agreed with the statement. This finding corroborates our conclusion that the general attitude towards investment in agribusiness was positive in our sample of financial advisers, as manifested by the positive coefficient on the ASC for the investment alternatives in classes 1 and 2 , which in total accounted for $88 \%$ of the respondents. On the other hand, the number of respondents who chose the bank account in all six choice tasks, the so-called serial opt-outers, was 18 , i.e. $2 \%$ of all respondents. However, their opt-out preference appears not to be systematically related to aversion to agribusiness, because only 3 of those 18 respondents disagreed with the statement on the attractiveness of food production firms as investment target. The number of opt-out choices varied between 56 and 84 in six choice tasks, which corresponds to 6.6-9.9\% of respondents in a choice task. Therefore, the reverse describes the number of investors who were in principle interested in agricultural cooperatives, and this appears be more than $90 \%$ of all respondents.

Observed characteristics could be included in the LCM to explain class membership with, for instance, socio-economic or demographic information, attitudes, or perceived values. However, if the observed respondent characteristics were used in the LCM, the class allocation of the respondents would not be purely based on their choices, but rather a function of the respondent characteristics. Incorporating individual characteristics as covariates in the LCM would restrict the parameters of one of the classes to zero in order to explain the class membership (Boxall and Adamowicz 2002). By using the logit model, we were able to directly present the effects for all three latent investor classes. This method has also been employed, for example, by Czajkowski et al. (2014).

The latent class model estimates the conditional class probabilities for each individual. These probabilities are used to identify the class membership, which is then explained in a logit regression model with the individual-specific background factors. Table 4 reports the results of the logit models separately run for all three investor classes. While the explanatory power of the included variables is rather low, a set of key variables appears to profile the investors in clearly separate dimensions. The identity and risk aversion variables were elicited from the responses to the statements "Rural life forms an important part of my identity" and "Direct stock investments are too risky". The subjects were requested to indicate on a Likert scale from 1 to 5 their agreement with the statements, where 1 denotes strong disagreement and 5 denotes strong agreement. The identity variable was dichotomized so that 1 denotes that an individual has agreed with the statement. The higher the subjective risk evaluation, the more risk averse a person is interpreted to be.

Both a self-reported rural identity and risk aversion were found to be relevant determinants of class membership. Individuals with a rural identity had a greater probability of belonging to class 2 . On the contrary, investors in class 1 were more likely to be those respondents who did not identify with a rural lifestyle. Rural identity did not affect the probability of opting out or membership of class 3.

Corroborating our earlier interpretation of the differences in risk tolerance between the latent classes, the risk aversion coefficient indicates that investors belonging to classes 2 and 3 were more risk averse based on their own judgment. The coefficients for risk aversion were positive and statistically significant. The opposite was true in class 1 , as the negative coefficient suggests that investors in this class were more willing to take risks in pursuing higher returns. Of the other explanatory variables, only female gender and a higher number of years in the sector (i.e. more experience) profiled the investors in class 2. Male respondents were more likely to belong to class 1 . Being in a manager position did not explain class membership. Class membership was not explained by locational variables, a dummy for a rural living environment, or the workplace structure in the person's current place of domicile, measured as the share of inhabitants in the postal code area employed in the agricultural sector. 
Table 4. Binary logit for investor class membership

\begin{tabular}{|c|c|c|c|}
\hline Variable & $\begin{array}{c}\text { Class } 1 \\
\text { (SD) }\end{array}$ & $\begin{array}{c}\text { Class } 2 \\
\text { (SD) }\end{array}$ & $\begin{array}{l}\text { Class } 3 \\
\text { (SD) }\end{array}$ \\
\hline Constant & $\begin{array}{c}1.84 * * * \\
(0.23)\end{array}$ & $\begin{array}{c}-2.18 * * * \\
(0.25)\end{array}$ & $\begin{array}{c}-2.76^{* * *} \\
(0.34)\end{array}$ \\
\hline Identity & $\begin{array}{c}-0.30^{*} \\
(0.18)\end{array}$ & $\begin{array}{c}0.37 * * \\
(0.18)\end{array}$ & $\begin{array}{l}-0.11 \\
(0.27)\end{array}$ \\
\hline Risk aversion & $\begin{array}{c}-0.45^{* * *} \\
(0.07)\end{array}$ & $\begin{array}{c}0.37 * * * \\
(0.07)\end{array}$ & $\begin{array}{c}0.24^{* *} \\
(0.10)\end{array}$ \\
\hline Female & $\begin{array}{c}-0.38^{* *} \\
(0.18)\end{array}$ & $\begin{array}{c}0.39 * * \\
(0.20)\end{array}$ & $\begin{array}{c}0.16 \\
(0.28)\end{array}$ \\
\hline Experience & $\begin{array}{l}-0.01 \\
(0.01)\end{array}$ & $\begin{array}{l}0.01 * \\
(0.01)\end{array}$ & $\begin{array}{l}-0.005 \\
(0.01)\end{array}$ \\
\hline Manager & $\begin{array}{c}0.12 \\
(0.19)\end{array}$ & $\begin{array}{l}-0.21 \\
(0.20)\end{array}$ & $\begin{array}{c}0.17 \\
(0.28)\end{array}$ \\
\hline Living rural & $\begin{array}{l}-0.12 \\
(0.23)\end{array}$ & $\begin{array}{l}-0.10 \\
(0.24)\end{array}$ & $\begin{array}{c}0.41 \\
(0.31)\end{array}$ \\
\hline Production structure & $\begin{array}{l}-0.03 \\
(0.03)\end{array}$ & $\begin{array}{c}0.04 \\
(0.03)\end{array}$ & $\begin{array}{l}-0.03 \\
(0.06)\end{array}$ \\
\hline Living rural $\mathrm{x}$ production structure & $\begin{array}{c}0.03 \\
(0.03)\end{array}$ & $\begin{array}{l}-0.04 \\
(0.03)\end{array}$ & $\begin{array}{c}0.04 \\
(0.06)\end{array}$ \\
\hline $\mathrm{N}$ of observations & 782 & 782 & 782 \\
\hline R squared & 0.08 & 0.07 & 0.02 \\
\hline Chi squared & 85.46 & 66.97 & 11.37 \\
\hline
\end{tabular}

\section{Discussion}

This study applied the choice experiment method in a novel setting of investments in agricultural firms. The globalization of agricultural and food markets has also intensified the competition faced by agricultural producer organizations. The sourcing of outside investment capital from non-members has motivated the emergence of innovative cooperative structures (Chaddad and Cook 2004). However, the strand of the literature focusing on these new organizational forms omits the perspective of an outside investor and the question of in which form the residual and control rights provide sufficient incentives for them to invest. A large questionnaire dataset comprising the responses of professional financial market subjects enabled testing of the instrument design. The choice experiment data were analyzed using a latent class model, which uncovered preference heterogeneity among the investor sample.

In our pool of 845 non-member investors, the majority of the respondents expressed interest in the currently hypothetical, new kinds of cooperative investment instruments and willingness to invest in producer-owned firms that are involved in food production. Three investor classes were distinguished based on their attribute preferences: return-seeking, ownership-oriented and risk-averse investors. The latent class modeling of the choice experiment data allocated some $88 \%$ of the respondents to the two first classes, in which the investors on average preferred the given investment instruments, while the remaining $12 \%$ were classified into the third category, in which no investment was preferred over the investment instruments. Only two percent of investors opted out in all the choice tasks presented in the questionnaire, and less than $10 \%$ chose the opt-out in one choice task.

These findings suggest that the implementation of new investment instruments in Finnish agricultural cooperatives might be received with positive demand in the market. The attributes that were most preferred in the choice experiment appeared to be the return of capital at a nominal value, i.e. the capital is secured during the investment period, while the opportunity to gain from the appreciation on the firm value was preferred among investors found in class 2, and a fixed interest return, voting rights, and a high expected return, also accepting the high associated risk, was preferred among investors found in class 1 . In comparison to the alternative cooperative models presented by Chaddad and Cook (2004), these new instruments would move the Finnish cooperatives launching them towards 'investor-share cooperatives' presented in the typology. In that particular model, the ownership rights of 
the cooperative are not restricted to members, but the shares are not converted to publicly traded common stock. By relaxing some of the restrictions on the traditional cooperative form, the disincentive of members to invest in the cooperative could also be relieved. A modification of the 'member-investor cooperative' model of the typology of Chaddad and Cook (2004) could be introduced in conjunction with the investor-share model, since in that model, the members could also benefit from the distribution of returns in proportion to shareholdings and the appreciability of cooperative shares. By also allowing the ownership rights for non-member investors, agricultural cooperatives could solve financial constraints and facilitate their growth efforts. However, the producers would have to give up part of their control, as suggested by the preference for voting rights in our choice experiment.

Preferences elicited in choice experiment studies are conditional on the design of the choice tasks. In this study, the willingness to invest in new cooperative instruments was contrasted with the given alternative to keep the savings in a bank account. There may be respondents who chose the given investment alternatives only because they are expected to yield a higher rate of return than a deposit in a bank account. However, this choice design is more realistic than if the alternatives were described as any other stock investments, because that would have required a detailed description of the reference sector and it would have changed the setting to agribusiness versus some other sector. Instead of that, the objective of this design was to test the attributes and their feasibility if the new instruments were implemented, and for this purpose, the definition of the reference alternative as a bank account yielding low interest is suitable and not a source of significant bias. The question of portfolio allocations between different sectors is worth including in future studies, which could investigate the amount of investment capital that agribusiness firms can potentially attract from outside investors.

A self-reported rural identity was positively related to membership of the ownership class in which the investors preferred a 'producer-like' position. This finding is line with prior evidence that investment decisions are affected by social characteristics (Coval and Moskowitz 2001, Huberman 2001, Morse and Shive 2011). While Morse and Shive (2011) focused on cross-country differences in local group identification and patriotism and found that patriotism is related to home bias in equity selection, this study established the relationship between identity and the preferred features of investment instruments. Of the social influence factors that we tested, the identity variable was specifically found to explain class membership positively in class 2 and negatively in class 1, whereas the current place of domicile of the respondent was not associated with investment preferences. Therefore, we cannot confirm the effects on economic decisions of familiarity through the living environment. Our findings thus differ from those of Coval and Moskowitz (2001), who reported a preference for investing close to home, although this paper did not test the home bias as such, but rather the link between the proximity of agriculture in the living environment and preferences for agricultural investments.

Who controls the firm appears to be irrelevant concerning the willingness to invest. The majority ownership of producers does not even drive away the return-seeking, least rurally-minded investors. The concern that a strong block owner would divert returns at the expense of minority investors does not gain support in this survey dataset. Investment capital for agricultural producer cooperatives also appears to be available from those investors who do not identify with rural lifestyle and agricultural producers. This class of investors is not motivated by voting rights, but rather prefers a good return potential. Only the risk-averse class, representing the minority of the respondents, would refrain from investing in the new instruments. Nevertheless, for these investors, the forms of investment instruments that offer security of the capital and a riskless return may be prospective alternatives for participating in the financing of agricultural producer cooperatives.

Overall, the results of this study are potentially useful in the marketing and design of financial instruments in agribusiness. Our results demonstrate how new features of investments can be tested and how distinct investor clienteles can be identified. For managers of capital-seeking agricultural firms, the results indicate that investment capital could potentially be sourced from outside investors using new financial strategies if the terms and conditions of cooperative investor shares are designed properly. While caution is needed in the generalization of stated preferences derived from choice experiment studies to eventual outcomes, the hypothetical cooperative investment instruments presented in this study were not rejected outright in our sample of informed investors. Although the financial advisers were requested to assess the attributes and to express their preferences as private persons, by presenting the idea of introducing new kinds of investment instruments in agricultural cooperatives, the questionnaire served as a means to pre-test the feasibility of their launching in markets. If financial market professionals did not have expressed interest towards them at all, the opening of Finnish agricultural cooperatives to outside investors could be a mission impossible. 
By linking the self-reported rural identity variable that was elicited in the questionnaire to the investment choices, our results encourage the promotion of agricultural organizations and food production as investments. When redesigning the agricultural cooperative model and the new investment instruments, the decision makers in cooperatives should be informed of our findings that one size does not fit all, as some investors expect good returns, some seek capital security, and voting rights are more important to some investors than others. Instead of creating one new share class for outside investors, our results on investor heterogeneity suggest that the financing strategy would be more successful in attracting new equity capital if many share classes are designed with different levels of ownership rights. With respect to members having to forfeit voting power to outside investors, our results may be reassuring, as in the investor class in which voting rights were preferred, the class members were found to have a rural identity and were not seeking high returns. Thus, the interests of those outside investors might be quite well aligned with producers. However, in order to attract investors like those segmented in class 1 , who represented $55 \%$ of the respondents, some tranche of the new instruments should be able to provide an attractive rate of return, even though these investors may not require voting rights.

\section{Conclusion}

Being the first study in examining the preferences of investors, who are not members in agricultural producer cooperatives, our results provide two-fold implications regarding the availability of new investment capital for growing cooperatives. First, the investors in our showed interest towards the new cooperative investment instruments developed in this study. The majority of the respondents in the choice experiment chose the provided investing alternatives over the option of not investing in the agricultural cooperatives and food production. Second, the results of the latent class model indicate that about one third of the respondents would be interested in voting rights as a prerequisite of investing in the cooperative, while the half of the investors appear to prefer return over the voting attributes. The rural ties of the respondent are positively related to the preference for voting rights among those respondents who are classified as ownership-oriented investors.

Further research could investigate the required rate of return for new cooperative investments, the potentially available investment amounts, and how they are related to the other portfolio holdings and the characteristics of the investors.

\section{References}

Akerlof, G. \& Kranton, R. 2000. Economics and identity. The Quarterly Journal of Economics 115: 715-753. https://doi. org/10.1162/003355300554881

Anastassiadis, F. \& Musshoff, O. 2013. Evaluating the role of financial flexibility in farmers' investment decisions using latent class analysis. Paper prepared for presentation at the 87th Annual Conference of the Agricultural Economics Society, University of Warwick, United Kingdom.

Baker, G. \& Burnham, T. 2001. Consumer response to genetically modified foods: Market segment analysis and implications for producers and policy makers. Journal of Agricultural and Resource Economics 26: 387-403.

Balcombe, K., Bitzios, M., Fraser, I. \& Haddock-Fraser, J. 2014. Using attribute importance ratings within discrete choice experiments: An application to valuing bread attributes. Journal of Agricultural Economics 65: 446-462. https://doi.org/10.1111/14779552.12051

Bank of Finland 2017. Interest rate statistics. https://www.suomenpankki.fi/en/Statistics/interest-rates/

Bateman, H., Islam, T., Louviere, J., Satchell, S. \& Thorp, S. 2011. Retirement investor risk tolerance in tranquil and crisis periods: Experimental survey evidence. Journal of Behavioral Finance 12: 201-218. https://doi.org/10.1080/15427560.2011.620199

Batsell, R. \& Louviere, J. 1991. Experimental analysis of choice. Marketing Letters 2: 199-214. https://doi.org/10.1007/BF02404072

Bechtold, K.-B. \& Abdulai, A. 2014. Combining attitudinal statements with choice experiments to analyze preference heterogeneity for functional dairy products. Food Policy 47: 97-106. https://doi.org/10.1016/j.foodpol.2014.05.007

van Bekkum, O. \& Bijman J. 2006. Innovations in cooperative ownership: Converted and hybrid listed cooperatives. Paper presented at the 7th international conference on management in agrifood chains and networks, Ede, The Netherlands, 31 May - 2 June 2006.

Bijman, J., lliopoulos, C., Poppe, K., Gijselinckx, C., Hagedorn, K., Hanisch, M., Hendrikse, G., Kühl, R., Ollila, P., Pyykkönen, P. \& van der Sangen, G. 2012. Support for farmers' cooperatives; Final report. November 2012, Wageningen UR, Netherlands. 127 p.

Birol, E., Karousakis, K. \& Koundouri, P. 2006. Using choice experiment to account for preference heterogeneity in wetlands attributes: The case of Cheimaditita wetland in Greece. Ecological Economics 60: 145-156. https://doi.org/10.1016/j.ecolecon.2006.06.002

Bolton, P. \& von Thadden, E. 1998. Blocks, liquidity, and corporate control. Journal of Finance 53: 1-25. https://doi.org/10.1111/00221082.15240

Boxall, P. \& Adamowicz, W. 2002. Understanding heterogeneous preferences in random utility models: a latent class approach. Environmental and Resource Economics 23: 421-446. https://doi.org/10.1023/A:1021351721619 
Caputo, V., Scarpa, R., \& Nayga R. Jr. 2016. Cue versus independent food attributes: The effect of adding attributes in choice experiments. European Review of Agricultural Economics: 1-20, forthcoming.

Caputo, V., Nayga R. Jr. \& Scarpa R. 2013. Food miles vs. carbon emissions information for food transport footprint: modeling assumptions and WTP estimates from stated food choice. Australian Journal of Agricultural and Resource Economics 57: 465-482. https://doi.org/10.1111/1467-8489.12014

Carson, R., Louviere, J., Anderson, D., Arabie, P.,Bunch, D., Hensher, D., Johnson, R., Kuhfeld, W., Steinberg, D., Swait, J., Timmermans, H. \& Wiley, J. 1994. Experimental analysis of choice. Marketing Letters 5: 351-368. https://doi.org/10.1007/BF00999210

Cassidy, A. \& McGrath, B. 2014. The relationship between 'non-successor' farm offspring and the continuity of the Irish family farm. Sociologia Ruralis 54: 309-416. https://doi.org/10.1111/soru.12054

Chaddad, F. \& Cook, M. 2004. Understanding new cooperative models: An ownership-control rights typology. Review of Agricultural Economics 26: 348-360. https://doi.org/10.1111/j.1467-9353.2004.00184.x

Chaddad, F., Cook, M. \& Heckelei, T. 2005. Testing for the presence of financial constraints in US agricultural cooperatives: an investment behavior approach. Journal of Agricultural Economics 56: 385-397. https://doi.org/10.1111/j.1477-9552.2005.00027.x

Chaddad, F. \& Iliopoulos, C. 2013. Control rights, governance, and the costs of ownership in agricultural cooperatives. Agribusiness An International Journal 29: 3-22. https://doi.org/10.1002/agr.21328

Coval, J. \& Moskowitz, T. 1999. Home bias at home: Local equity preference in domestic portfolios. Journal of Finance 54: 20452073. https://doi.org/10.1111/0022-1082.00181

Czajkowski, M., Kadziela, T. \& Hanley, N. 2014. We want to sort! Assessing households' preferences for sorting waste. Resource and Energy Economics 36: 290-306. https://doi.org/10.1016/j.reseneeco.2013.05.006

De Marchi, E., Caputo, V, Nayga, R. Jr. \& Banterle, A. 2016. Time Preferences and Food Choices: Evidence from a Choice Experiment. Food Policy 62: 99-109. https://doi.org/10.1016/j.foodpol.2016.05.004

Dhar, R. \& Simonson, I. 2003. The effect of forced choice on choice. Journal of Marketing Research 40: 146-160. https://doi. org/10.1509/jmkr.40.2.146.19229

Duflo, E. \& Saez, E. 2002. Participation and investment decisions in a retirement plan: The influence of colleagues' choices. Journal of Public Economics 85: 121-148. https://doi.org/10.1016/S0047-2727(01)00098-6

Emberger-Klein, A., Zapilko, M. \& Menrad, K. 2015. Consumers' preference heterogeneity for GM and organic food products in Germany. Agribusiness An International Journal 32: 203-221. https://doi.org/10.1002/agr.21439

Fama, E. 1980. Agency problems and the theory of the firm. Journal of Political Economy 88: 288-307. https://doi.org/10.1086/260866 Federation of Finnish Financial Services 2015. Work in the financial services sector. March 2015.

French, K. \& Poterba, J. 1991. Investor diversification and international equity markets. American Economic Review 81: 222-226. https://doi.org/10.3386/w3609

Glaser, M., Langer, T., Reynders, J. \& Weber, M. 2007. Framing effects in stock market forecasts: The difference between asking for prices and asking for returns. Review of Finance 11: 325-357. https://doi.org/10.1093/rof/rfm008

Greene, W. 2007. NLOGIT version 4.0 reference guide. Econometric Software Inc, Plainview, NY, USA. 173 p.

Greene W. \& Hensher D. 2003. A latent class model for discrete choice analysis: contrasts with mixed logit. Transportation Research Part B: Methodological 37: 681-698. https://doi.org/10.1016/S0191-2615(02)00046-2

Guiso, L., Sapienza, P. \& Zingales, L. 2004. The role of social capital in financial development. American Economic Review 94: 526556. https://doi.org/10.1257/0002828041464498

Harrison, G. \& List, J.2004. Field experiments.Journal of Economic Literature 42:1009-1055. https://doi.org/10.1257/0022051043004577

Hensher, D. 2004. Identifying the influence of stated choice design dimensionality on willingness to pay for travel time savings. Journal of Transport Economics and Policy 38: 425-446.

Hensher, D. 2010. Hypothetical bias, choice experiments and willingness to pay. Transportation Research Part B 44: 735-752. https://doi.org/10.1016/j.trb.2009.12.012

Hensher, D. \& Rose, J. 2007. Development of commuter and non-commuter mode choice models for the assessment of new public transport infrastructure projects: A case study. Transportation Research Part A: Policy and Practice 41: 428-443. https://doi. org/10.1016/j.tra.2006.09.006

Hensher, D., Rose, J. \& Greene, D. 2015. Applied choice analysis. 2nd edition, Cambridge University Press. 1216 p. https://doi. org/10.1017/СBO9781316136232

Hess, S. \& Rose, J. 2009. Should reference alternatives in pivot design SC surveys be treated differently? Environmental and Resource Economics 42: 297-317. https://doi.org/10.1007/s10640-008-9244-6

Hole, A., Kolstad, J. and Gyrd-Hansen, D. 2013. Inferred vs. stated attribute non-attendance in choice experiments: A study of doctors' prescription behavior. Journal of Economic Behavior \& Organization 96: 21-31. https://doi.org/10.1016/j.jebo.2013.09.009 Hong, H., Kubik, J. \& Stein, J. 2004. Social interaction and stock-market participation. Journal of Finance 59: 137-163. https://doi. org/10.1111/j.1540-6261.2004.00629.x

Homburg, C., Wieseke, J. \& Hoyer, W. 2009. Social identity and the service-profit chain. Journal of Marketing 73: 38-54. https:// doi.org/10.1509/jmkg.73.2.38

Huberman, G. 2001. Familiarity breeds investment. Review of Financial Studies 14: 659-680. https://doi.org/10.1093/rfs/14.3.659

Jaeck, M. \& Lifran, R. 2014. Farmers' preference for production practices: A choice experiment study in the Rhone River Delta. Journal of Agricultural Economics 65: 112-130. https://doi.org/10.1111/1477-9552.12018 
Johnston, R., Boyle, K., Adamowicz, W., Bennett, J., Brouwer, R., Cameron, T., Hanemann, M., Hanley, N., Ryan, M., Scarpa, R., Tourangeau, R. \& Vossler, C. 2017. Contemporary guidance for stated preferences studies. Journal of the Association of Environmental and Resource Economists 4:319-405. https://doi.org/10.1086/691697

Kang, J. \& Stulz, R. 1997. Why is there a home bias? An analysis of foreign portfolio ownership in Japan. Journal of Financial Economics 46: 3-28. https://doi.org/10.1016/S0304-405X(97)00023-8

Knack, S. \& Keefer, P. 1997. Does social capital have an economic payoff? The Quarterly Journal of Economics 112: 1251-1288. https://doi.org/10.1162/003355300555475

Kontoleon, A. \& Yabe, M. 2003. Assessing the impacts of alternative 'opt-out' formats in choice experiment studies: Consumer preferences for genetically modified content and production information in food. Journal of Agricultural Policy Research 5: 1-43.

Kragt, M. \& Llewellyn, R. 2014. Using a choice experiment to improve decision support tool design. Applied Economic Perspectives and Policy 36: 351-371. https://doi.org/10.1093/aepp/ppu001

Kruse, J. \& Thompson, M. 2003. Valuing low probability risk: survey and experimental evidence. Journal of Economic Behavior \& Organization 50: 495-505. https://doi.org/10.1016/S0167-2681(02)00039-2

La Porta, R., Lopez-de-Silanes, F. \& Shleifer, A. 1999. Corporate ownership around the world. Journal of Finance 54: 471-517. https://doi.org/10.1111/0022-1082.00115

Ladenburg, J., Dahlgaard, J. \& Bonnichsen, O. 2010. Testing the effect of a short cheap talk script in choice experiments. Institute of Food and Resource Economics, University of Copenhagen. FOI Working Paper 2010/11.

Lagarde, M. 2013. Investigating attribute non-attendance and its consequences in choice experiments with latent class models. Health Economics 22: 554-567. http://dx.doi.org/10.1002/hec.2824. https://doi.org/10.1002/hec.2824

Lam, S., M Ahearne, Y. Hu \& Schillewaert, N. 2010. Resistance to brand switching when a radically new brand is introduced: A social identity theory perspective. Journal of Marketing 74: 128-146. https://doi.org/10.1509/jmkg.74.6.128

Lancaster, K. 1966. A new approach to consumer theory. Journal of Political Economy 74: 132-157. https://doi.org/10.1086/259131

Landry, C. \& List, J. 2007. Using ex-ante approaches to obtain credible signals for value in contingent markets: Evidence from the field. American Journal of Agricultural Economics 89: 420-429. https://doi.org/10.1111/j.1467-8276.2007.01017.x

Lehmann, E. \& Neuberger, D. 2001. Do lending relationships matter? Evidence from bank survey data in Germany. Journal of Economic Behavior \& Organization 45: 339-359. https://doi.org/10.1016/S0167-2681(01)00151-2

Louviere, J., Flynn, T. \& Carson, R. 2010. Discrete choice experiments are not conjoint analysis. Journal of Choice Modelling 3: 57-72. https://doi.org/10.1016/S1755-5345(13)70014-9

Louviere, J., Hensher, D. \& Swait, J. 2000. Stated choice methods: Analysis and application. Cambridge University Press. 420 p. https://doi.org/10.1017/CBO9780511753831

Lusk, J., Roosen, J. \& Fox, J. 2003. Demand for beef from cattle administered growth hormones or fed genetically modified corn: A comparison of consumers in France, Germany, The United Kingdom, and The United States. American Journal of Agricultural Economics 85: 16-29. https://doi.org/10.1111/1467-8276.00100

Malmendier, U. \& Nagel, S. 2011. Depression babies: Do macroeconomic experiences affect risk taking? The Quarterly Journal of Economics 126: 373-416. https://doi.org/10.1093/qje/qjq004

McFadden, D. 1974. Conditional logit analysis of qualitative choice behavior. In: Zarembka P. (ed.). Frontiers in Econometrics. New York: Academic Press. p. 105-142.

McFadden, D. 1986. The choice theory approach to market research. Marketing Science 5: 275-279. https://doi.org/10.1287/ mksc.5.4.275

McIntosh, E. and Ryan, M. 2002. Using discrete choice experiments to derive welfare estimates for the provision of elective surgery: implications of discontinuous preferences. Journal of Economic Psychology 23: 367-382. https://doi.org/10.1016/S01674870(02)00081-8

Morey, E. Thacher J. \& Breffle W. 2006. Using angler characteristics and attitudinal data to identify environmental preference classes: A latent-class model. Environment and Resource Economics 34: 91-115. https://doi.org/10.1007/s10640-005-3794-7

Morse, A. \& Shive, S. 2011. Patriotism in your portfolio. Journal of Financial Markets 14: 411-440. https://doi.org/10.1016/j.finmar.2010.10.006

Nagy, R. \& Obenberger, R. 1994. Factors influencing individual investor behavior. Financial Analysts Journal 50: 63-68. https:// doi.org/10.2469/faj.v50.n4.63

Pool, V., Stoffman, N. \& Yonker, S. 2014. The people in your neighborhood: Social interactions and mutual fund portfolios. Journal of Finance 70: 2679-2732. https://doi.org/10.1111/jofi.12208

Portes, R. \& Rey, H. 2005. The determinants of cross-border equity flows. Journal of International Economics 65: 269-296. https://doi.org/10.1016/j.jinteco.2004.05.002

Probst, L., Houedjofonon, E., Ayerakwa, H. \& Haas, R. 2012. Will they buy it? The potential for marketing organic vegetables in food vending sector to strengthen vegetable safety: A choice experiment study in three West African countries. Food Policy 37: 296-308. https://doi.org/10.1016/j.foodpol.2012.02.014

Rose, J. \& Hess, S. 2010. Dual-response choices in pivoted stated choice experiments. Transportation Research Record: Journal of the Transportation Research Board 2135: 25-33. https://doi.org/10.3141/2135-04

Scarpa, R., Gilbride, T., Campbell, D. \& Hensher, D. 2009. Modelling attribute nonattendance in choice experiments for rural landscape valuation. European Review of Agricultural Economics 36: 151-174. https://doi.org/10.1093/erae/jbp012

Scarpa, R., Philippidis, G. \& Spalatro, F. 2005. Product-country images and preference heterogeneity for Mediterranean food products: A discrete choice framework. Agribusiness An International Journal 21: 329-349. https://doi.org/10.1002/agr.20051 
Scarpa, R. \& Rose, J. 2008. Design efficiency for non-market valuation with choice modelling: how to measure it, what to report and why. The Australian Journal of Agricultural and Resource Economics 52: 253-282. https://doi.org/10.1111/j.1467-8489.2007.00436.x

Schulz, N., Breustedt, G. \& Latacz-Lohmann, U. 2014. Assessing farmers' willingness to accept "greening": Insights from a discrete choice experiment in Germany. Journal of Agricultural Economics 65: 26-48. https://doi.org/10.1111/1477-9552.12044

Shen, J. 2009. Latent class model or mixed logit model? A comparison by transport mode choice data. Applied Economics 41 : 2915-2924. https://doi.org/10.1080/00036840801964633

Official Statistics of Finland (OSF) 2013. Households' assets [e-publication]. ISSN=2242-3230. 2013. Helsinki: Statistics Finland (referred: 30.11.2017). http://www.stat.fi/til/vtutk/2013/vtutk_2013_2015-04-01_tie_001_en.html

Svendsen, G. \& Svendsen, G. 2000. Measuring social capital in: The Danish co-operative dairy movement. Sociologia Ruralis 40 : 72-86. https://doi.org/10.1111/1467-9523.00132

Swait, J. 1994. A structural equation model of latent segmentation and product choice for cross-sectional revealed preference choice data. Journal of Retailing and Consumer Services 1: 77-89. https://doi.org/10.1016/0969-6989(94)90002-7

Swait, J. \& Adamowicz, W. 2001. Choice environment, market complexity, and consumer behavior: A theoretical and empirical approach for incorporating decision complexity into models of consumer choice. Organizational Behavior and Human Decision Processes 86: 1-27. https://doi.org/10.1006/obhd.2000.2941

Tajfel, H. \& Turner, J. 1979. An integrative theory of intergroup conflict. In: Tajfel, H., Austin, J. \& Worchel, W. (eds.). The social psychology of intergroup relations. Monterey, California, USA: Brooks/Cole. p. 33-47.

Thurstone, L. 1927. A law of comparative judgment. Psychological Review 34: 273-286. https://doi.org/10.1037/h0070288

Train, K. 1998. Recreation demand models with taste differences over people. Land Economics 74: 230-239. https://doi. org/10.2307/3147053

Valentinov, V. 2007. Why are cooperatives important in agriculture? An organizational economics perspective. Journal of Institutional Economics 3: 55-69. https://doi.org/10.1017/S1744137406000555

Wen, C.-H. \& Lai, S.-C. 2010. Latent class models of international air carrier choice. Transportation Research Part E 46: $211-221$. https://doi.org/10.1016/j.tre.2009.08.004

Yue, C., Zhao, S. \& Kuzma, J. 2015. Heterogeneous consumer preferences for nanotechnology and genetic-modification technology in food products. Journal of Agricultural Economics 66: 308-328. https://doi.org/10.1111/1477-9552.12090 